UDK: 821.163.41.08 Црњански М.; 811.163.41:81'373.45

\title{
• STRANI JEZICI I SUMATRAIZAM MILOŠA CRNJANSKOG
}

\section{GORDANA JANJUŠEVIĆ LEKOVIĆ'}

U radu se analizira relacija strani jezici - sumatraizam u umjetničkom tekstu velikog srpskog i jugoslovenskog pisca Miloša Crnjanskog. Upotreba stranih riječi (ne u smislu tuđica, pozajmljenica, već autentičnih riječi, izraza i fraza iz stranih jezika) kod (rnjanskog ima izrazitu stilsku funkciju i korespondira sa sumatraističkom vizijom svijeta, što se i pokazuje na odabranim primjerima. U drugom dijelu rada data je jezičko-stilska analiza dužeg odlomka iz proznog teksta Crnjanskog, gdje se istražuje efekat upotrebe stranih jezika u sadejstvu sa drugim karakterističnim stilskim postupcima, u kontekstu poetike sumatraizma.

Ključne riječi: strani jezik, sumatraizam, povezanost svijeta, empatija naratora, princip ekvivalentnosti, postupak osamostaljivanja, ponavljanja, postupak imenovanja.

\section{UVOD}

Sumatraizam Miloša Crnjanskog, kao pravac unutar jedne osobene poetike, podrazumijeva prije svega ideju i viziju sveopšte povezanosti svijeta. U okviru svog umjetničkog prosedea Crnjanski je prepoznatljiv po originalnim stilskim rješenjima, određenim odabirima u jeziku koji korespondiraju sa značenjskim i idejnim slojevima književnog teksta. U ovom radu polazimo od hipoteze da je i stilski markirana upotreba stranih jezika u tekstu ovog pisca u saglasju sa sumatraističkim osjećanjem sveprisutnih veza (u prostoru, ali i u vremenu). Na primjerima ćemo dokazivati da su sumatraističke veze Crnjanskog, kao poetičko-filozofska kategorija, prisutne i u samom jeziku/jezicima, ali i da su izražene umjetničkom upotrebom različitih jezika, pored maternjeg. Ovdje valja istaći da pomenuti postupak upotrebe stranih jezika u tekstu Miloša Crnjanskog mi ne dovodimo isključivo u vezu sa sumatraizmom, ali polazimo od hipoteze da je jedna od funkcija ovog postupka - i to veoma važna - dočaravanje sumatraističke vizije i doživljaja svijeta. Tim aspektom zastupljenosti stranih jezika u književnom tekstu Crnjanskog bavimo se u ovom radu. Korpus za istraživanje i izvor primjera predstavlja tekst Miloša Crnjanskog. Konkretno, u samom radu biće zastupljeni primjeri iz sljedećih

1 Kontakt podaci (Email): gordana.lekovic.10@gmail.com 
djela: Seobe (Seobe I) i Druga knjiga Seoba (Seobe II, Seobe III), Roman o Londonu, Kod Hiperborejaca I, Kod Hiperborejaca II, Knjiga o Mikelanđelu. U posebnom odjeljku ćemo dati analizu dužeg odlomka iz romana Kod Hiperborejaca.

\section{POETIKA CRNJANSKOG I SUMATRAIZAM}

Poslije prve knjige poezije (Lirika Itake, 1919) - pjesama koje je pisao za vrijeme Prvog svjetskog rata u uniformi austrijskog oficira, i po kojima je prepoznat kao avangardni pjesnik, buntovnik i „anarhist“, ekspresionist, Crnjanski će se oglasiti pjesmom Sumatra, neuporedivom lirskom vizijom sveprostornih veza i kosmičke ljubavi, sumatraističkog mira što izvire iz osjećanja da je sve u vezi. Programskoj pjesmi Sumatra ubrzo će se pridružiti i manifestni tekst Objašnjenje 'Sumatre', napisan na zahtjev urednika Srpskog književnog glasnika Bogdana Popovića (gdje je pjesma po prvi put i objavljena 1920. godine). Od pjesnika se tražilo da objasni čitaocima ta nova "hipermoderna buncanja" kao što je Sumatra. Crnjanski je to učinio tako što je ovoj stihovnoj tvorevini pridružio još jedan nesumnjivo umjetnički tekst koji ujedno, kao što već i naslov kaže, objašnjava i okolnosti i način na koji je pjesma nastala, ali i smjernice i načela te nove poetike. Pjesnik odgovara da novo vrijeme traži nov izraz, a da će „hipermoderna buncanja“ najbolje izraziti doživljaj svijeta onih koji su u proteklom ratu na svojoj koži i te kako osjetili "hipermoderne senzacije" (v. Crnjanski 1966, IV: 214-216). Sumatraizam (rnjanskog kao muzika jezika i vizija svijeta obnavlja pokidane veze, spaja areale velike geografske udaljenosti, ali zaista donosi revoluciju u poeziji posredstvom sublimne vizije jedinstva svijeta i univerzalne ljubavi, a sve to kroz prizmu poetskog subjekta koji je tako snažno prisutan da je gotovo opipljiv, premda lebdeći, nevidljiv, sveprisutan - dok mu ruka miluje trešnje u zavičaju, vrhove Urala i ledene gore, istovremeno.

Binarna opozicija daleko - blisko realizuje se u sumatraističkom tekstu Crnjanskog kao jedna od najvažnijih. Ali, to je opozicija koja u sumatraizmu biva pomirena, relativizovana, dovedena do ideje da i daleko može da postane blisko. Sumatraizam uspostavlja veze između dva pola binarnih opozicija na način da se jedno značenje preliva u drugo, jedno u drugom ogleda, da se sva ta značenja šire i razlivaju svekolikim prostorom, a nadasve prostorima teksta. Premda je ta struktura labava, raščlanjena, „razbijena“, sa čestim neočekivanim pauzama - pri čemu važnu ulogu ima poetska funkcija interpunkcije ona je i dovoljno vezana brojnim ekvivalentnostima (glasovnim, ritmičkim, motivskim, leksičko-semantičkim, sintaksičkim). Jednu od važnih lingvostilističkih odlika predstavlja upadljiva zastupljenost postupaka osamostaljivanja, i to na svim sintaksičkim nivoima (o postupcima osamostaljivanja v. npr. Kovačević (2000: 342-355)). Tekst se prividno razgrađuje, raščlanjuje da bise ostvario viši stepen kohezije. Jezičke jedinice se udaljavaju, fragmentiraju, distanciraju se gramatički, formalno, da bi se na semantičkom planu otvorio prostor za oneobičenje značenjskih veza.

Sama leksička jedinica veze u tekstu Miloša Crnjanskog javlja se kao znak sumatraističkog doživljaja svijeta.

Sada istražujemo posebnu umjetničku funkciju koju u kontekstu sumatraizma ima postupak upotrebe stranih jezika. 


\section{SUMATRAIZAM I STRANI JEZICI}

Zvona u Rimu zazvoniše na molitvu večernju. Ne večernju, nego „vječornu“. Kažem vječornu... Jedna jedina reč jednog jezika dovoljna je, da bi čovek pripadao jednom narodu.

\section{Poljska.}

Čitava jedna zemlja može, ma kako to neverovatno bilo, da stane, u jedno jedino srce ljudsko. I da preživi večno. Dovoljno je da kažem samo jednu jedinu reč vječorna - mesto večernja, pa da ugledam, kad zatvorim oči, čitavu tu zemlju. Varšavu koja gori, i morske talase koji se prelivaju po Pomoržu. Da ožive čitava sela u beskrajnoj kiši i snegu i da ime Varšave izgovore, na stotinu jezika, na svetu.

(Kod Hiperborejaca II, 101)

Ovaj doživljaj dalekog prostora koji počinje izgovaranjem riječi jednog jezika prisutan je u tekstu Crnjanskog, naročito kroz postupak ponavljanja koji podrazumijeva specifičnu sinonimiju - isti plan sadržaja (značenje) i različit plan izraza (oblik, zvučanje) riječi domaćeg i stranog jezika.

Višestruko je funkcionalna i umjetnički aktivna upotreba stranih jezika u djelu Crnjanskog. Ovdje moramo naglasiti da se ona javlja u većini tekstova i nesumnjivo u svim žanrovima u opusu ovog pisca. Nalazimo je u autobiografskoj prozi takođe.

U radu 'Maska' Miloša Crnjanskog Miočinović (2005) posmatra sličan postupak u kontekstu rečene drame, ali i drame kao književnog roda, ističući "fonični efekat" (ibid., 250) upotrebe stranih jezika. Pozivajući se na Šklovskog (1969: 28)², pominjući onu opijenost zvukom izvan smisla, autorka dotiče upravo ono sumatraističko, onu misao koju je i sam Crnjanski iskazao kada je napisao da je dovoljna „jedna jedina reč jednog jezika" (njen zvuk, dakako, potom i značenje) da biste osjetili da pripadate jednom prostoru, ili narodu. No, postupak korišcenja stranih jezika kod Crnjanskog daleko prevazilazi okvire jedne drame, i drame uopšte, i bilo kog književnog roda ili žanra pojedinačno, i predstavlja jedno od važnih obilježja poetike ovog pisca, književni manir, stil - i na nivou opusa, ukrštajući se i te kako sa programskim smjernicama te poetike, odnosno - dovodeći se u vezu sa sumatraističkim doživljajem svijeta. Pritom, efekat koji proizvode i zvuk i grafički znak - ne izostaje ni u tekstovima koji nisu neposredno namijenjeni scenskom izvođenju, odnosno tome - da budu izgovoreni.

3.1. Empatični narator Miloša Crnjanskog ne samo da se uživljava u način na koji se riječi određenog jezika pišu, izgovaraju, čuju i razumiju, nego i u stavove svojih junaka prema jeziku.

Primjera u djelima pisca Miloša Crnjanskog, bez obzira na rod i žanr - zaista ima. Prirodno, oni su najfrekventniji u onim tekstovima gdje se literarni junak nalazi u stranoj zemlji, ili tamo odlazi, $i$ /ili se susreće sa govornicima stranog jezika, razgovara sa njima, i/ili čita nešto na stranom jeziku i sl. - a to su bezmalo sva literarna ostvarenja

2 Vidi Šklovski, V. 1969. 0 poeziji i zaumnom jeziku. U Uskrsnuće riječi. Zagreb: Stvarnost (citirano prema Miočinović 2005: 250). 
ovog pisca. Njegovi literarni junaci su dvojezični ili višejezični, znaju jezike, nalaze se u stranim zemljama, odlaze u strane zemlje, čitaju na stranim jezicima i prevode sa drugih jezika. Sasvim je razumljivo i da ponekad razmišljaju "duplirano", dvojezično, ili da njihovu misao do čitaoca donosi onaj tako nesvakidašnji narator, „sjenka sjenke", što se lako izmješta kroz prostor i vrijeme, lako ulazi u duševna stanja junaka, i gotovo neprimjetno preuzima ton, intonaciju, ritam njihovog govora - na različitim jezicima - prenoseći njegov sadržaj doslovce, kao direktan govor, ili samo u trećem licu, što je kod doživljenog govora ujedno najčešće i jedina razlika u odnosu na direktan govor.

Kada Pavle Isakovič ugleda u noći "neprolaznu nadeždu svoju“, „zvezdu Danicu“, a ubrzo potom izgovori, tiho, za sebe: „In Nacht ein Stern!“ - on je već u prostoru drugog jezika, ali svaki je jezički areal dovoljno prostran za san o „zvezdi":

On, međutim, video je, i u mračnoj noći, svoju neprolaznu nadeždu: zvezdu Danicu. A pošto je, poslednjih dana, morao da brblja nemecki, reče u sebi nemecki: „In Nacht ein Stern!“ Pavle Isakovič bio je sujeta sujetstva.

(Seobe II, 193)

Kada autobiografski narator Hiperborejaca s oduševljenjem recituje Kardučija na italijanskom, on doživljava svoje pripadanje Rimu daleko intenzivnije nego što bi inače doživio taj prostor:

... Ja mu odgovaram da, ja, - jer sam stranac - volim svaku Italiju, a što se tiče Kardučija, i ja volim jedan njegov stih, i govorim ga sebi, to jest Rimu, često, ujutru, kad otvorim prozore svoga stana, preko puta Sent Anđela. To je onaj stih u kom Karduči kaže Rimu: Obuhvati me, Rime, plavetnilom. Suncem me osvetli, Rime. Cingimi, o Roma, d'azzuro, di sole m'illumina, o Roma.

(Kod Hiperborejaca I, 180)

Riječ stranog jezika odvodi pripovjedača i književnog junaka Crnjanskog, opet sumatraistički, u neku davnu prošlost, javlja se kao veza sa jednim toposom, ali i vremenom, u primjeru koji slijedi - sa djetinjstvom:

Sedam kod jednog praznog stola, na ulici, pored zida, i posmatram žuti, mutni, Tibar. Tiberis flavus, kažem sebi, latinski, kao u detinjstvu.

(Kod Hiperborejaca I, 26)

Direktan govor književnog junaka u nekim dionicama teksta miješa se sa doživljenim govorom naratora, što za posljedicu ima sugestivnost umjetničkog postupka, pri čemu upotreba različitih jezika takođe ima bitnu funkciju:

Ponavljao je: „No, kapetan, ne grustjite po prošlomu!” a kad vide da ga Pavle ne razume, protumači mu, nemecki, da ne valja vraćati se u prošlost. (Volkov je rekao: „Nein, du nicht hoffnungslos! Grubeln nicht gut!”) 
Volkov je bio sad nasmejan, i, prišavši Pavlu, činilo se da će da ga zagrli. Njegove oči su se smejale veselo. Kaže, i on je prošle godine bio u velikoj tuzi. Umro mu je otac. Ne može se, međutim, večno tugovati.

Pa ponovi opet: „No, kapetan, ne grustjite po prošlomu!“

(Seobe II, 271)

Sećam se kako mi je, pri rastanku, večeras, onaj novinar, moj prijatelj, prebacivao, što u Rimu nisam zadovoljan. Veli, ima informaciju da će Francuzi bombardovati Rim i Italiju. A Italija je tako lepa (La povera bella). (...) Italija je tako vedra. Rim ima najbolju odbranu od bombardovanja iz vazduha. To je, kaže, papa. Nema čega da se bojim, a ta moja melanholija, to je znak starosti, zamor od života - taedium vitae - kaže latinski.

(Kod Hiperborejaca I, 26)

Iz stanice se čuo otkucaj telegrafa, kao neki ritam šivačice. Jesen je, sa sumrakom, bila već stigla u okolinu. („Osenj. Padajut listja.“ - čujem kako neko, ruski, mrmlja. A taj što mrmlja, znam, to je junak ovog romana, koji se vraća u London, sav promenjen.)

(Roman o Londonu, 337)

3.2. Deskripcija plana izraza, opisivanje zvuka različitih jezika svijeta, takođe je jedan od karakterističnih postupaka.

Susedi, dabogme, nisu mogli čuti, šta ta žena i taj čovek govore, kad se zatvoriše vrata, ali da su to i mogli čuti, ne bi bili razumeli, ništa. Razgovor se vodio na nekom jeziku, za koji su mislili da je poljski, - a bio je ruski. Čuli bi bili i nekoliko uobičajenih, francuskih, reči, ali, sve je, ostalo, bio neki tihi, tužni, šušanj, ljupkih, mekih, neobičnih, nepoznatih, ruskih, reči.

(Roman o Londonu, 24)

Poljski je strašan i divan, zvuk mu je nevjerovatan, kao grmljavina, ali to je i lijep jezik - misli pripovjedač Crnjanskog. Stoga je upravo paradoksalno da se dva tako različita zvuka u percepciji govornika neslovenskih jezika - doživljavaju kao nešto što se gotovo ne razlikuje.

0 italijanskom - sam pisac, kao i njegovi brojni naratori i književni junaci - izriču divljenje i opijenost vanrednim, melodioznim zvukom, koji se stapa sa ljepotom Italije. Navodimo jedan primjer:

Kažem: da stavimo tačku, jednom za svagda, na Petrarku.

Neka ona pristane da mi čita Mikelanđela, a ja ću njoj priznati Petrarku, koji je krunisan za poetu. Priznaću ga, ne zbog njegovog sadržaja, nego zbog lepote stihova, slikova, Petrarkine forme. To je velika lepota talijanskog jezika.

(Knjiga o Mikelanđelu, 252) 
Kako literarni junaci Crnjanskog izgovaraju riječi stranih jezika, kakvo je njihovo znanje tih jezika uopšte, o tome takođe saznajemo iz kazivanja naratora. A razlika u stepenu i kvalitetu rečenog znanja jeste ogromna - od epohe do epohe, od junaka do junaka, odnosno - od jednog do drugog teksta ovog pisca. Rjepnin i Nađa sa lakoćom govore strane jezike, čitaju i prevode strane tekstove (Roman o Londonu).

Jedino su mališani Mil Hila imali najlepše mišljenje, o tom strancu, I voleli ga. (...) Razumevali su njegov govor, na engleskom, savršeno, I govorili, da lepo priča.

(Roman o Londonu, 34)

Mogao bi da posluži kao prevodilac. Zna jezike. Na primer, telefonist, u nekoj pošti.

(Roman o Londonu, 79)

Isakoviči, oficiri iz XVIII vijeka (Seobe) razumiju "nemecki", naročito naređenja i vojničke komande, shvataju čak i knjige, govore "nemecki” po potrebi, ali (za razliku od Rjepnina poliglote, ili autofiktivnog naratora romana Kod Hiperborejaca) - slabo, smušeno, rogobatno.

Obratićemo pažnju na odlomak iz Druge knjige Seoba, gdje se potencira takođe postupak imenovanja, nominacije (uz prisustvo i same lekseme ime, i uz to glagola koji se odnose na pisanje, izgovaranje, sricanje, čitanje - imena). Ime kao znak protiv zaborava, trag prošlosti - pokušava Isakovič da izgovori i zapamti, služeći se jezicima koje je ili vrlo slabo govorio, ili nešto bolje razumijevao. Opet ono sumatraističko izvire i iz samih imena jezika koja upućuju na tuđe i daleke prostore koji su sa nama ipak u nekoj vezi:

Isakovič je, i nemecki, govorio slabo, smušeno, rogobatno, a franceski je čuo samo od svojih zarobljenika, u okolini Praga. Nije imao ni pojma o tome šta piše u franceskoj knjizi, koju mu je Višnjevski dao, ali je u njoj zagledao crteže, dugo. To je bila istorija franceskog đenerala, čije je ime Isakovič samo sricao: V-i-c-o-m-t-e T-u-r-e-n-n-e.

Nemecke knjige ipak je dobro shvatao.

A najviše mu se dopale, slepe, oči, na skulpturi - koja je bila crtež biste rimskog đenerala, koji se Julije Cezar zvao.

(Seobe III, 81)

Arhaični oblici nemecki, franceski, prenose nas (sumatraističkom vezom) i u neke druge prostore Evrope, i u osamnaesti vijek kao istorijsko i romaneskno vrijeme. Sintaksostilem - kumulacija homofunkcionalnih jedinica (priloga slabo, smušeno, rogobatno) - tu je da nam dočara način na koji je Pavle Isakovič, junak Druge knjige Seoba, govorio "nemecki". Sljedeći, postupkom osamostaljivanja izdvojen pasus, kaže nam suprotno: da je nemecke knjige ipak dobro shvatao. A franceski nije znao uopšte, ali se nad imenom jednog „franceskog đenerala" ipak zaustavio i sricao: V-i-c-o-m-t-e T-u-r-e-n-n-e. Grafički na ovaj način prikazano ime dočarava "sricanje" Isakoviča, ali 
i to kako ime očarava Isakoviča, to jest - istovremeno ističe i važnost imena, u kojem svaka grafička jedinica kao da nosi značenje cjeline, svaka biva ponaosob naglašena, i sa ostalima istovremeno povezana.

U nastavku ćemo obratiti pažnju upravo na postupak imenovanja kao markantnu jezičko-stilsku odliku Crnjanskog, sada u kontekstu upotrebe stranih jezika.

3.3. Postupak nominacije $\mathbf{i}$ pronominacije, naglašenog imenovanja $\mathbf{i}$ preimenovanja ljudi i toposa, i uopšte svega što se obilježava vlastitom imenicom - prepoznatljiv je u tekstu ovog pisca. Brojni primjeri pokazuju da je takođe povezan sa sumatraističkim idejama teksta, motivom seoba, ali i da se javlja u vezi sa postupkom upotrebe stranih jezika (pisanje imena - izvorno i prilagođeno, transkripcija, varijacije u imenu, tumačenja „etimologije" samog imena, odgonetanje denotata kojim je ime inspirisano i sl. - sve to ulazi u sferu nekih drugih jezika i drugih kultura i, samim tim, tiče se i upotrebe stranih jezičkih kodova u umjetničkom kodu (rnjanskog).

U primjeru koji slijedi izrazita kumulacija ženskih ličnih imena dodatno je oneobičena izvornom grafijom stranog jezika. Ova dionica teksta završava se paralelizmom poredbenih konstrukcija kojima se opisuje raskoš zvuka:

On se začudio, najviše, ženskim imenima, koja treba umetnuti u muževljevu adresu. Tako su romantična. Eto, na primer, nekoliko, koja je ispisao danas na jednu cedulju, u azbučnom redu: Alice, Ami, Ann, Arabella, Aurora, Beatrice, Caroline, Cecily, Clarissa, Clementine, Constance, Daphne, Deborah, Delia, Diana, Eleonor, Elvira, Emily, Esther, Felicity, Georgina, Geraldine, Harriet, Irene, Jenny, Kitty, Laelia, Lavinia, Leah, Lella, Margaret, Marianne, Mary, Maud, Molly, Naomi, Philomela, Phoebe, Porcia, Priscilla, Rachel, Rebecca, Rose, Ruth, Sarah, Silvia, Theodora, Thisbe, Victoria, Vivian. Kao da gugutke guču. Kao da tice pevaju.

(Roman o Londonu, 152)

Narator Crnjanskog nerijetko „prevodi“ lična imena, prati njihove seobe iz jezika u jezik:

Polk nekada slavnog obersta Vuka, što će reći Vlka, Volfganga, Isakoviča.

(Seobe I, 25)

Kako je ime najneposrednije povezano sa identitetom, to su junaci Crnjanskog osjetljivi na pogrešno izgovaranje njihovih imena:

Kad ga je vratar, Mister White, ugledao, idući dan, pogledao ga je nehatno. Srećom, Rjepnin ga je to jutro oslovio vratarevim pravim imenom, a nije rekao: „Dobro jutro, Mister Blake". Mister Blek je bio piljar. Niko ne voli, kad se zove crni, da ga oslove, „beli“, a niko ne voli kad se zove „beli", da ga oslove „crni“. Međutim, Rjepnin je stalno mešao ta imena. Vratar ga je, zbog toga, izbegavao. Smatrao ga je za ludog Poljaka.

(Roman o Londonu, 495) 
S druge strane, kako su seobe, mijene, promjene jedina konstanta na svijetu, to su promjene oblika i značenja riječi, pa i kolebanja ličnog imena i sa njim i identiteta - neizbježne. „Zbrka” u izgovoru i značenjima, isprepletenost svega na svijetu koja se katkad doima kao "zamršenost" - skriva takođe neke duboke veze među jezicima, Ijudima i narodima. U narednom primjeru, junak Romana o Londonu, negodujući zbog toga što mu ime u tuđini i u tuđem jeziku stalno poprima nove oblike i značenja istovremeno pokušava da dokuči nedokučivu etimologiju riječi koje su očito zajedničke i vrlo udaljenim jezicima:

Kad je, iz daljine, čuo, da dolazi voz, pitao se, i to, kako će se popeti u vagon, ovakav, ćopav. Pri toj pomisli ispade mu iz ruke i štaka, pa se saginje teško. Međutim, kad je ekspres dojurio, Rjepnin se popeo u voz lakše nego što je očekivao. Pomogli su mu. Iz kola za spavanje uzviknuše čak i njegovo ime. Ovako: Mister Ričpejn.

Grofica Panova omogućila mu je da može da spava, do Londona. Namestili su mu i postelju, i nogu na postelju, vodoravno, a donesoše mu i čaj. A posle, i jedan noćni sud, od porcelana. (Porcelan Englezi zovu: Kina, Čajna, a tako zovu i šolje čaja: china.)

Kad je ostao sam na postelji, taj Rus, opet, mrmlja, ljutito, svoje ime, koje ne znaju da izgovaraju u Engleskoj. Da, da, - čujem kako mrmlja. On je sad, u Engleskoj, čovek sastavljen od bogatstva i bola? A katkad se pretvara u iglu. Mister Ričpin. A reč prah, međutim, - to ga je začudilo, - tu, na kraj sveta, - ruska reč prah, značila je i u starom govoru Kornvala: prah. (Sve je na svetu ludo.)

(Roman o Londonu, 339)

Seobe riječi iz jezika u jezik, njihovo pojavljivanje odnekud, ko zna odakle i iz kog jezika - notirane su više puta u tekstu Crnjanskog. Etimološka tumačenja nekih leksema iz stranih jezika pripisuju se katkad naratoru, katkad književnim junacima, uvijek su interesantna i pojačavaju onaj sumatraistički doživljaj svepovezanosti svijeta.

\section{EFEKAT UPOTREBE STRANIH JEZIKA U SADEJSTVU SA DRUGIM STILSKIM POSTUPCIMA. JEZIČKO-STILSKA ANALIZA JEDNOG ODLOMKA IZ ROMANA KOD HIPERBOREJACA}

U primjeru koji slijedi sagledaćemo jednu epizodu teksta romana Kod Hiperborejaca, u kojoj se sumatraističke veze iskazuju nizom jezičkih postupaka, pa i upotrebom stranih jezika.

Prvo što zapažamo jesu postupci imenovanja, stilski markirani postupci nominacije, karakteristični u jeziku i stilu Crnjanskog, a zatim i specifična sinonimija o kojoj u ovom radu govorimo - paliloško udvajanje značenja, na srpskom i na stranim jezicima. U odlomku je riječ o Holanđanima koji su išli „tamo“, u polarne predjele o kojima govori i fiktivni "ja"- narator, autofikcija Crnjanskog. Ti putnici u daleke krajeve i misionari opisani su u kratkim potezima kao sumatraisti, sa osobinama i svojstvima sličnim 
onima koje prepoznajemo kod literarnog junaka i lirskog subjekta Miloša Crnjanskog. $\mathrm{Ni}$ oni ne odlaze (otići, ići, karakteristični glagoli sa značenjem kretanja, putovanja, koji korespondiraju sa opštom tematikom seoba i želje za daljinama) - „samo zarade radi". Nisu puki materijalisti. Traže "nešto više". Ovaj uzlet u visinu, leksičkom jedinicom "više", koja za trenutak zvuči kao da sadrži nijansu nečeg metafizičkog, apstraktnog, neizrecivog - vrlo brzo se konkretizuje sintagmom „put u Aziju“, kao realnim sadržajem ovog "više“. Traženje veza ipak ostaje ona sumatraistička (i/ili hiperborejska) arhisemska komponenta ove strukture. Tu su i prepoznatlijiva semantička polja leksičke jedinice "led", kao jednog od oblika praelemenata u kojem su sadržane neke od ključnih leksema teksta Crnjanskog uopšte (arhisemsko polje praelemenata), kao i leksičke jedinice Sunce i noć iz međusobno antonimičnih semantičkih polja. U odlomku zapažamo i karakteristične postupke ponavljanja i osamostaljivanja (v. Kovačević 2000: 287-318, 342-355) realizaciju poetskog principa ekvivalentnosti kao načela poezije (v. Lotman 1976), koji raščlanjuju strukturu čineći je muzičkom, ritmičkom, i uopšte - poetičnom. U sadejstvu sa pobrojanim stilskim postupcima, efekat upotrebe stranih jezika dolazi do punog izražaja:

Nisu, međutim, ni Holanđani išli tamo samo zarade radi. Jacob Haemskerc i Willem Barentz i van der Scheling i Jan Cornelius, tražili su tamo i nešto više: put u Aziju. Per mare Hyperboreum ad Orientalis orbis navigari. Ad Cathajam \& Indiam.

Kakva čudna imena imaju ti ljudi, kaže Neapolitanka. Niko ta imena u Neapolju ne bi mogao izgovoriti. Pa jesu li uspeli?

Nisu, kažem. Ble, kaže, sa uzdahom, da je sve bilo uzalud. Put u Aziju, kroz to carstvo večnog leda, nisu našli. Uzalud su pokušavali i životom svojim plaćali. In vanum tentatum fuit.

Trudna gospa me onda pita, a da li su bar znali šta ih tamo čeka?

$\mathrm{Ne}$, kažem, nisu mogli znati, odlazili su u nepoznato, u Hiperboreju, iz koje povratka nema. Znali su samo toliko, da su to polarni regioni i da ih čekaju ledena mora. Frigus. Istočnu stranu Špicbergena nikad videli nisu. Dvina - Dvina flu - činila im se kraj Evrope. Terminus.

Špicbergen, međutim, znali su dobro.

Ble spominje, na svojoj karti, takozvani ledeni zaliv. Eysand. Zeleni zaliv. Grenharbor. Magdalenin zaliv. Magdalenen Bay. Sva je ta pristaništa obišao i moj brod.

Spominje Ble i Hiperborejce. Nije ih, dabome, video, ali ponavlja o njima ono, što su antički istoričari govorili. Na obali Azije, kaže, stanuju Hiperborejci, tamo je Sunce nesvakidašnja pojava, noć je tamo bez prekida. Nox continua est. to su jedino znali da mu kažu, već i, Mela, i Plinije, i Solinus. 
U topografiji tog Holanđanina, još se oseća strah u carstvu večnog leda. Za jedno mesto kaže samo toliko da je veliko brdo leda. Der Groote Ysbergh. Ali kad naiđu na ptice tamo, klikću. Jedan zaliv naziva prosto ptičji zaliv. Vogel Bay.

Iako je, pre njega, Julius Scaligerius, pisao da u tim polarnim predelima retko ćarlijaju vetrići, blagi (Adeo namque rari sunt Lephyri), i, da je to mračna pustoš (Vada infinita), i da zima traje, kaže, tamo deset meseci (Hyems sevit decem menses), Ble piše da Hiperborejci ipak žive sretni. Oni žive, kaže, negde, iza svega toga. Tamo gde neko večno Sunce sja.

(Kod Hiperborejaca I, 66, 67)

Nabrajanje imena kao da su jedna izgovorna cjelina - emfatički polisindet bez zareza, u kojem je opetovani veznik $i$ „brza" i gotovo neprimjetna proklitika (Jacob Haemskerc i Willem Barentz i van der Scheling i Jan Cornelius) - ističe postupak imenovanja, nominacije, stilski markiran u umjetničkom tekstu ovog pisca.

Nekoliko pasusa iza, sličan postupak ima suprotna intonacijska obilježja:

To su jedino znali da mu kažu, već i, Mela, i Plinije, i Solinus.

Ovdje se veznik intonaciono naglašava postupkom osamostaljivanja (segmentiranje zarezima elemenata u nabrajanju). Istovremeno, i sam veznik na ovaj način, kao riječ sa redukovanim značenjem, postaje dodatno semantizovan. U istom tekstu dakle imamo emfatički polisindet kao kumulaciju imena u koordiniranoj strukturi bez zareza, i na određenoj, ne previše udaljenoj poziciji - opet emfatički polisindet - kumulirana imena, s tim što je sad koordinirani niz razbijen pauzama, a sama imena su iz nekog drugog jezika i sa drugog prostora (drugačijeg zvuka i grafičkog znaka, tj. pisma, uz to još - za razliku od imena u prethodno navedenoj rečenici - transkribovana, prilagođena domaćem izgovoru i pismu jezika kojim se služi autor). Izmjene ritma utiču na ovaj način na zvukovnu organizaciju teksta. Međutim, čitav niz jezičko-stilskih postupaka doprinosi muzikalnosti i ritmičnosti strukture, i u saglasju stoje sa značenjima.

Samo u ovom odlomku nalazimo dvanaest puta antroponime - osam koji se javljaju jednom, i jedan koji se opetuje u sprezi sa glagolima govorenja (riječ je 0 nekome ko o Hiperboreji kazuje: Ble, kaže, ..., Ble spominje..., Spominje Ble..., Ble piše). Pet od osam antroponima nosi obilježje izvorne grafije stranih jezika: Jacob Haemskerc, Willem Barentz, van der Scheling, Jan Cornelius, Julius Scaligerius - što pojačava utisak tajanstvenosti, dodatno potenciran značenjima koja u nastavku slijede.

Leksema ime prisutna je u tekstu u konstrukciji s atributom: čudna imena. Uz to ide i glagol izgovoriti (imena), što je još jedno prepoznatljivo značenje kod Crnjanskog: tuđa imena su čudna, neizgovorljiva. Narator uvodi slušaoce i na ovaj način u neku daljinu, Hiperboreju, kao u kakvu bajkovitu zemlju čuda. Strana imena i njihov grafički znak javljaju se s tim značenjem.

Samo u ovom odlomku imamo dva naratora: jedan je već pomenuti „ja“- narator i glavni lik romana, a drugi je Ble. Njihovi glasovi se gotovo stapaju. Njih dvojica zajedno 
kazuju priču o dalekoj Hiperboreji, koju su već antički istoričari spominjali, kao da kazuju neku bajku. Slušaoci su Neapolitanci. Priča o Severu - ljudima sa Juga. I povremeni glas slušalaca kroz doživljeni govor stapa se sa glasovima kazivača, u čijoj naraciji upotreba stranih jezika ima višestruki efekat, potcrtavajući rečenu doživljenost i sugestivnost i prenoseći slušaoca/čitaoca u daleke nepoznate jezike, prostore, vremena (vidjeli smo da narator vjeruje u takvu moć riječi, u njenu i evokativnu i tvoračku snagu: ona ne samo da rekonstruiše epohe i oživljava prostore, nego, izgovorena, makar i strancu koji se za trenutak našao u tom jeziku, daruje osjećanje pripadanja: „Jedna jedina reč jednog jezika dovoljna je da bi čovek pripadao jednom narodu."

(Kod Hiperborejaca II, 101).

No, semantika čuđenja neophodna je da bi dočarala hiperborejsku bajku:

Kakva čudna imena imaju ti ljudi, kaže Neapolitanka. Niko ta imena u Neapolju ne bi mogao izgovoriti. Pa jesu li uspeli?

Amfibolična igra riječi kroz postavljeno pitanje Pa jesu li uspeli? - pitanje je koje se pozicijski nadovezuje na rečenicu Niko ta imena ne bi mogao izgovoriti. - tako da se u prvi mah čini da se odnosi upravo na to. Pitanje je, međutim, usmjereno na sadržaj iz prethodnog pasusa; sama upitna rečenica je u distantnoj poziciji u odnosu na antecedent, što je interesantna igra uspostavljanja smisaonih veza između distantnih sintaksičkih cjelina, u nekom luku kojim se povezuju strukture „iznad“ teksta.

Toponimi su takođe markantno prisutni, i takođe upućuju na međusobno vrlo udaljene areale - geografske i jezičke, što je još jedan u nizu sumatraističkih postupaka. Njihovi zvukovi koji se u tekstu miješaju, kao i njihov različiti vizuelni izraz (latinički alfabeti stranih jezika i znak \&, ćiriličko pismo) - sve se sliva u sumatraističku priču 0 Hiperboreji, uspostavljajući veze među imenima i ljudima sa različitih prostora i u različitim vremenima. Još su antički istoričari (drevnost, Jug) opisivali Hiperboreju (večnost, Sever, carstvo večnog leda), i sve je to u vezi sa onim što mnogo kasnije priča Ble (neka bliža prošlost), pa i sam narator Hiperborejaca koji je autofikcija Crnjanskog (romaneskna sadašnjost). Tako se vremena i prostori pretapaju, slivaju, a objedinjujuća tačka im je Hiperboreja koja simbolizuje vječnu, svuda prisutnu čovjekovu težnju da dosegne ono "nešto više". Ovo sumatraističko slivanje (credo „Sve je u vezi, sve se sliva" - v. Crnjanski 1966, IV: 214-216) prate zvuci i grafija, miješanje i slivanje samih ljudskih jezika.

I karakterističan glagol „ponavljati” u ovoj strukturi nalazi mjesta, ali ovdje sa značenjem koje ukazuje na lijenost ljudskog duha i uma da o nečemu što je bilo ponovo i drugačije promisli i sudi; dakle - na značenje okamenjenih predstava koje se stvaraju bezbrojnim ponavljanjem uvijek istog suda ili pisanog traga o nečemu, i koje stvaraju trajno ograničenje ljudskoj spoznaji i saznavanju prošlosti (ponavljati kao papagaj - konstrukcija je koja se ponavlja u tekstu Crnjanskog, sa opisanim značenjem; napomenimo još jednom da ova semantička nijansa kontrastira drugom značenju glagola ponavljati (se), koje ukazuje na ponavljanje iskustava, istina, sličnih sudbina , „u bezbroj primeraka").

Ponavljanja kao lirski i sintaksički paralelizmi nose jaku umjetničku informaciju u ovom odlomku, naročito u kombinaciji sa specifičnim uzastopnim parnim ponavljanjem 
plana sadržaja i naizmjeničnim smjenjivanjem plana izraza u strukturama sa stranim jezicima (paliloška ponavljanja, sinonimija):

Ble spominje, na svojoj karti, takozvani ledeni zaliv. Eysand. Zeleni zaliv. Grenharbor. Magdalenin zaliv. Magdalenen Bay. Sva je ta pristaništa obišao i moj brod.

Ponavljanje riječi zaliv na kraju ritmičke cjeline sa silaznom intonacijom ima zvučne efekte epifore između čijih su članova u nizu umetnuti sinonimni članovi sa drugačijim planom izraza (to jest - na stranom jeziku), čija je intonacija takođe silazna. Cijela dionica podsjeća na izgovaranje kakve muzičke dionice po taktu, na ritmičko taktiranje:

\section{ledeni zaliv. \\ Eysand. \\ Zeleni zaliv. \\ Grenharbor. \\ Magdalenin zaliv. \\ Magdalenen Bay.}

Svaka, samo u planu sadržaja opetovana jedinica (tj. - sa istim denotatom, ali na drugom jeziku) zvuči kao talas koji se povlači, pošto je, nadolazeći u prethodnoj ritmičkoj cjelini svoj udar i rečenični akcenat potvrdio zvukom koji se ponavlja na kraju ritmičke i sintaksičke dionice: zaliv. Međutim, i „tajanstvene" riječi iz stranih jezika posredstvom denotata se ulančavaju sa prethodnom dionicom, tako da je struktura istovremeno ritmički raščlanjena i „skrivenim“ zajedničkim sadržajem povezana. Na raznim jezicima - imena za isto mjesto na globu, potvrđuju da je tamo kročila noga mnogih ljudi, koji su tamo pristizali sa različitih, međusobno često veoma udaljenih tačaka. Ovu implicitnu misao na kraju pasusa potvrđuje rečenica:

\section{Sva je ta pristaništa obišao i moj brod.}

Riječi pristanište i brod pripadaju polju odisejske semantike (u tekstu Crnjanskog prisutne od prve objavljene pjesme - Sudba, 1904. godine, gdje su lađa i bura ključne riječi; motiv modernog odisejstva, na homerski, ali i ulisovski, džojsovski način, snažno će obilježiti kasnije i život i stvaralaštvo Miloša (rnjanskog, prožimajući tekst ovog pisca na nivou i mikro i makrokompozicije). Ono što je u ovoj rečenici posebno znakovito jeste prisustvo veznika $i$ ( $\mathrm{moj}$ brod), koji upravo ukazuje na veze - sa onima koji su na istim mjestima već bili.

U odlomku zapažamo neke izrazito hiperborejske pojmove - sve liči na jezu i zimsku čaroliju, što je ponovo asocijacija na bajku: carstvo večnog leda, strah u carstvu večnog leda: ledena mora. Frigus; veliko brdo leda. Der Groote Ysbergh, mračna pustoš (Vada infinita) - jesu izrazi koji sadrže semantiku leda i mraka, i kao takvi diskretno nagovještavaju strah od smrti (ne slučajno, oni koji su tamo išli - nisu se vratili, odlazili su u Hiperboreju, iz koje povratka nema, kao da odlaze u kakvu zimsku 
bajku, ili u bijelu smrt, u smrt kao u bajku; ne slučajno, na sličan način završiće život i Pavle Isakovič). Semantičko polje praelemenata nastavlja ovdje sa igrom značenja i semantičkih kombinacija. Strani jezici - bilo da su u pitanju skandinavski idiomi ili latinski jezik - unose potvrdu tih značenja i donose atmosferu udaljenih krajeva svijeta. Ne slučajno, u istom pasusu u kojem se pominje „nepoznato", tj. „Hiperboreja, iz koje povratka nema" (smrt je ono nepoznato - nameće se misao, logično) - pominje se i kraj, il „terminus", a u latinskom obliku čak kao osamostaljena, redukovana sintaksička cjelina: (...) kraj Evrope. Terminus.

Premda je u odlomku vrlo uočljiv sistem binarnih opozicija (dan -noć, led-Sunce) - nekako ih miri hiperborejska bajka koja kaže da će ulazak u vječnost biti obasjan Suncem:

Ble piše da Hiperborejci ipak žive sretni. Oni žive, kaže, negde, iza svega toga. Tamo gde neko večno Sunce sja.

Analizirajući u ovom primjeru sadejstvo, svojevrsnu sinergiju stilskih postupaka u sintaksičkim i stilskim strukturama, ukazali smo takođe na upotrebu leksičkih jedinica i izraza iz stranih jezika koja doprinosi sugestivnosti umjetničkog teksta, nadasve poetizovane sumatraističke vizije svepovezanosti svijeta.

\section{ZAKLJUČAK}

U tekstu Miloša Crnjanskog analizirali smo primjere upotrebe stranih jezika $s$ ciljem da utvrdimo vezu između ovog postupka i sumatraizma kao poetike i pravca Crnjanskog, koji podrazumijeva osjećanje sveopšte povezanosti svijeta.

Strani jezici, odnosno inostrani kodovi kao prvostepeni jezički sistemi, u tekstu su povremeno zastupljeni kao umjetnički aktivan element. Njihova funkcija jeste semantičko i stilsko bogaćenje teksta, odnosno usložnjavanje umjetničke poruke. Pisac koji se, na primjer, u čitavom svom opusu na ovaj ili onaj način bavio temom stranstvovanja, umio je da umjetnički funkcionalizuje i strani jezički kôd i učini ga upotrebljivim (djelimično, sporadično, i uporedo sa maternjim jezikom kao primarnim kodom), u cilju umjetničkog modelovanja teksta. Tako imamo česte primjere sinonimnih parova - na maternjem i stranom jeziku, koji, u zavisnosti od pozicije u umjetničkoj strukturi, obrazuju različite paralelizme, i iz kojih izvire složena semantička korelativnost. Zaključujemo na osnovu brojnih primjera da u tekstu ovog pisca sumatraistička vizija uključuje i areal ljudskog jezika/ljudskih jezika, te da su sveprostorne, svevremenske i svud prisutne veze u jednom originalnom umjetničkom postupku potcrtane i adekvatnom upotrebom drugačijih, tj. stranih, jezičkih kodova. 


\section{LITERATURA}

Crnjanski, M. 1966. Sabrana dela Miloša Crnjanskog I-X (I - Seobe I, II - Seobe II, III Seobe III, IV - Poezija, VII - Kod Hiperborejaca I, VIII - Kod Hiperborejaca II). Beograd: Prosveta.

Crnjanski, M. 2004. Roman o Londonu. Beograd: NIN/Zavod za udžbenike i nastavna sredstva.

Crnjanski, M. 2010. Knjiga o Mikelanđelu. Vršac: KOV.

Kovačević, M. 2000. Stilistika igramatika stilskihfigura. Kragujevac/Beograd: Kantakuzin. Lotman, J. M. 1976. Struktura umetničkog teksta, prevod i predgovor Novica Petković. Beograd: Nolit.

Miočinović, M. 2005. Maska Miloša Crnjanskog, Knjiga o Crnjanskom (225-253). Beograd: Srpska književna zadruga.

\section{SUMMARY}

\section{THE FOREIGN LANGUAGES AND MILOŠ CRNJANSKI'S SUMATRAISM}

In this paper we look at the use of foreign languages in the context of Sumatraism. We have shown how the idea of overall connectivity of the world corresponds to the chosen language. The use of foreign languages has been associated with the structure of narration and the empathy of the narrator. A separate section of this paper comprises the analysis of artistic text, in which we establish the connections between the use of foreign languages and certain techniques, that is - the stylistic techniques in interplay, intersecting their meanings and artistic effects. We have noticed the connections between the use of words from foreign languages and the techniques of repetition in the text. In this way, the text becomes enriched.

KEYWORDS: foreign language, Sumatraism, world connectivity, empathy of the narrator, principle of equivalence, disengaging technique, repetition, naming technique.

(Originalni naučni rad primljen 04.07.2014; ispravljen 01.12.2014; prihvaćen 15.12.2014) 